\title{
Legalitas Alat Bukti Elektronik Dalam Sistem Peradilan Pidana
}

\author{
Insan Pribadi \\ insan_pribadi@yahoo.com
}

\begin{abstract}
When a perpetrator of cybercrime is examined for a case settlement, the Criminal Procedure Code (KUHAP) has not clearly regulated the arrangement of electronic evidence as valid proof of evidence. What is the legality of electronic evidence in the criminal justice system? To answer this question, the researcher examined the subject matter using a normative juridical approach by analyzing the problem from the perspective of or according to existing regulations or laws, papers, articles, literature, and research findings as well as other scientific works related to this study. The Criminal Procedure Code has not explicitly regulated valid electronic evidence, which is related to the principle of legality in Law No. 11 of 2008 on Electronic Information and Transactions Article 54 Paragraph (1); therefore, electronic data can be used as valid evidence. The legality of electronic evidence is also stated in Electronic Information and Transactions Law in Chapter III about Information, Documents, and Electronic Signatures as well as the explanations of Article 44 and Article 5 of Electronic Information and Transactions Law. Referring to the stipulation as regards proof of evidence in the Criminal Procedure Code, a testing instrument must be available for electronic evidence to be declared valid at the trial, which is the same as other evidence that includes formal requirements and material requirements.
\end{abstract}

Keywords: Legality; criminal justice systemp; electronic evidence

\begin{abstract}
Abstrak
Ketika seorang pelaku kejahatan teknologi diperiksa dalam hal penyelesaian perkara, KUHAP belum mengatur secara jelas mengenai pengaturan alat bukti elektornik sebagai alat bukti yang sah dalam melakukan pembuktian. Lalu bagaimana legalitas alat bukti elektronik dalam sistem peradilan pidana? Untuk menjawab pertanyaan tersebut, maka peneliti mengkaji pokok permasalahan melalui pendekatan yuridis normatif, yaitu menganalisis permasalahan dari sudut pandang atau menurut ketentuan atau peraturan perundang-undangan yang berlaku, makalah, artikel, literatur, serta hasil penelitian dan karya ilmiah lainnya yang berhubungan dengan penelitian ini. KUHAP belum mengatur secara tegas mengenai alat bukti elektronik yang sah, hal ini berkaitan dengan adanya asas legalitas yang menyatakan bahwa UU No. 11 Tahun 2008 tentang ITE dalam Pasal 54 ayat (1), maka untuk menggunakan data elektronik dapat dijadikan sebagai alat bukti yang sah. Serta legalitas alat bukti elektronik dalam UU ITE dalam Bab III tentang Informasi, Dokumen, dan Tanda Tangan Elektronik, serta penjelasan dalam Pasal 44 dan Pasal 5 UU ITE. Mengacu pada ketentuan pembuktian yang diatur dalam KUHAP, harus ada alat penguji terhadap alat bukti elektronik agar alat bukti tersebut dapat dinyatakan sah di persidangan, sama seperti terhadap alat bukti lainnya, yaitu persyaratan formil dan persyaratan materiil.
\end{abstract}

Kata-kata Kunci: Legalitas; sistem peradilan pidana; alat bukti elektronik 


\section{Pendahuluan}

Perkembangan zaman semakin pesat yang diikuti dengan berkembangnya suatu teknologi informasi yang dapat membantu pekerjaan manusia, menjadi sarana edukasi maupun menjadi suatu ladang untuk mendapatkan pundi-pundi rupiah. Suatu teknologi merupakan salah satu alat yang dapat memudahkan manusia dalam segala aktifitas kegiatan dan hal ini tidak dapat dipisahkan satu sama lain, dan sudah menjadi suatu keterikatan antara manusia dan teknologi. Serta menjadi suatu alat yang modern, dimana melahirkan ilmu pengetahuan dan teknologi yang amat membantu umat manusia.

Salah satu dari produk ilmu pengetahuan dan teknologi adalah teknologi informasi yang telah membantu umat manusia dalam berinteraksi dengan manusia yang ada dalam komunitas lain dengan lebih mudah. Teknologi informasi membawa manusia pada suatu perdaban yang baru, dengan struktur sosial beserta tata nilainya, yaitu masyarakat berkembang menuju masyarakat baru yang berstruktur global dimana sekat-sekat negara mulai memudar yang akhirnya akan membawa dampak pada pergeseran nilai, norma, moral dan kesusilaan.

Suatu perdaban yang pada hal ini berdampak pada munculnya suatu komunikasi antara orang dengan orang, negara dengan negara dan hal ini bisa terjadi melalui lintas negara. Sehingga memunculkan suatu komunikasi yang tiada batas (borderless), orang dapat berkomunikasi dengan siapapun, dimanapun dan kapanpun maupun memperoleh informasi apapun yang sebelumnya belum pernah kita ketahui. Perkembangan ilmu, pengetahuan, teknologi, dan seni mengantarkan manusia memasuki era digital yang melahirkan internet sebagai sebuah jaringan, dan juga sebuah lambang eksklusivitas. Sebagai sebuah jaringan, internet mampu mengoneksikan antar subsistem jaringan menjadi satu jaringan super besar yang dapat saling terhubung (online) seluruh dunia.

Salah satu kejahatan yang ditimbulkan oleh perkembangan dan kemajuan teknologi informasi adalah kejahatan yang berkaitan dengan aplikasi internet. Kejahatan ini dalam istilah asing sering disebut dengan "Cyber Crime". Barda Nawawi Arif menggunakan istilah Tindak Pidana Mayantara untuk menunjuk jenis 
kejahatan yang berkaitan dengan aplikasi internet ${ }^{1}$. Aspek hukum dalam rezim hukum cyber cukup luas, yaitu dalam hukum administrasi, perdata, pidana. Ketiga bidang hukum cyber tersebut disebut cyberlaw. Internet selain bermanfaat positif bagi manusia, misalnya memudahkan semua urusan pengelolaan informasi, ternyata juga dapat mempunyai dampak negatif dan merugikan anggota masyrakat, misalnya dalam kasus pemalsuan data, penipuan, pencurian data, provokasi, pornografi, perjudian, pembajakan hak cipta. Kejahatan yang terjadi melalui atau terhadap jaringan komputer dalam dunia maya (di dalam jaringan internet) atau diluar jaringan tetapi menggunakan komputer, kejahatan ini lazim disebut cybercrime ${ }^{2}$.

Kemajuan teknologi yang merupakan hasil budaya manusia disamping membawa dampak positif, dalam arti dapat didayagunakan untuk kepentingan umat manusia juga membawa dampak negative terhadap perkembangan manusia dan peradabannya. Dampak negatif yang dimaksud adalah yang berkaitan dengan dunia kejahatan. J.E Sahetapy telah menyatakan dalam tulisannya, bahwa kejahatan erat kaitannya dan bahkan menjadi sebagian dari hasil budaya itu sendiri. Ini berarti semakin tinggi tingkat budaya dan semakin modern suatu bangsa, maka semakin modern pula kejahatan itu dalam bentuk, sifat, dan cara pelaksanaannya ${ }^{3}$. Istilah hukum pidana di bidang teknologi informasi merupakan istilah yuridis, artinya istilah tersebut sudah tertuang dalam peraturan perundangundangan, yaitu dalam Pasal 43 ayat (1) dan (2) UU Informasi dan Transaksi Elektronik. Dalam ketentuan tersebut diatur tentang Penyidik Pegawai Negeri Sipil dan penyidkan di bidang Teknologi Informasi ${ }^{4}$.

Berdasarkan UU ITE, Pasal 1 angka 3, pengertian Teknologi Informasi adalah suatu teknik untuk mengumpulkan, menyiapkan, menyimpan, memproses, mengumumkan, menganalisa, dan/atau menyebarkan informasi. Dalam konteks hukum di bidang teknologi informasi, pengertian teknologi informasi mengarah

${ }^{1}$ Abdul Wahid dan Mohammad Labib, Kejahatan Mayantara (Cyber Crime), Cetakan Kesatu (Bandung: Refika Aditama, 2005), hlm. 26.

2 Widodo, Hukum Pidana di Bidang Teknologi Informasi Cybercrime Law, Aswaja Pressindo, Yogyakarta, 2013, hlm. 8 .

${ }^{3}$ Abdul Wahid, Op. Cit., hlm. 26.

${ }^{4}$ Widodo, Op. Cit., hlm. 5 
pada pemanfaatan teknologi informasi dan komunikasi berbasi komputer. Serta pada Pasal 1 angka 14 UU ITE adalah alat untuk memproses data elektronik, magnetik, optik, atau sistem yang melaksanakan fungsi logika, aritmatika, dan penyimpanan. Pengertian komputer dalam konteks ini termasuk jaringan komputer sebagai basis jaringan sistem elektronik. Sistem elektronik juga digunakan untuk menjelaskan keberadaan sistem informasi yang merupakan penerapan teknologi informasi yang berbasis jaringan telekomunikasi dan media elektronik, yang berfungsi merancang, memproses, menganalisis, menampilkan, dan mengirimkan atau menyebarkan informasi elektronik ${ }^{5}$. Council of Europe dalam Convention on Cybercrime di Budapest 23 Nopember 2011 menyebut Cyber Crime sebagai kejahatan yang berhubungan dengan penyalahgunaan sistem computer. Namun karena Cyber Crime menggunakan suatu media yaitu Cyber Space untuk melakukan kejahatan dan menggunakan teknologi informasi dan telekomunikasi sebagai alat korban, maka berdasarkan Resolusi Majelis Umum PBB (Resolution of The General Assembly of United Nations) No. A/RES/55/63 tanggal 12 Januari 2001 tentang perlawanan terhadap tindak pidana penyalahgunaan teknologi informasi (Combating the Criminal Misuse of Information Technologies), yaitu istilah yang relevan untuk menyebut tindak pidana cyber crime adalah tindak pidana penyalahgunaan teknologi informasi dan telekomunikasi ${ }^{6}$.

Dengan demikian, pengertian hukum pidana di bidang teknologi informasi dalam hal ini adalah ketentuan-ketentuan pidana yang dapat diterapkan pada aktivitas manusia berbasis koputer dan dalam jaringan komputer di dunia maya (virtual) dalam hal mengumpulkan, menyiapkan, menyimpan, memproses, mengumumkan, menganalisis, dan/atau menyebarkan informasi dalam bentuk data, suara, dan, gambar7.

\section{Rumusan Masalah}

Berdasarkan uraian di atas, maka dirumuskan masalahnya, bagaimana legalitas alat bukti elektonik dalam sistem peradilan pidana?

${ }^{5}$ Ibid.

${ }^{6}$ Makalah disampaikan di Seminar "Penegakan Hukum Tindak Pidana Mayantara", Kepolisian RI Polda Jateng Semarang.

7 Widodo, Op. Cit, hlm. 7 


\section{Tujuan Penelitian}

Penelitian ini bertujuan untuk mengetahui legalitas alat bukti elektronik dalam sistem peradilan pidana.

\section{Metode Penelitian}

Dalam penulisan ini, peneliti menggunakan metode yuridis normatif dengan pendekatan peraturan perundanng-undangan untuk menganalisis kasus berdasarkan peraturan perundang-undangan yang berlaku, dan pendekatan konseptual untuk menjelaskan dan mengaitkan dengan teori-teori yang relevan.

Sumber data penelitian adalah sumber data sekunder yang didapat dari literatur dan sumber hukum primer, sekunder, serta tersier. Adapun sumber hukum utama yang dipakai dalam penelitan ini mencakup Undang-undang Informasi dan Transaksi Elektronik dan KUHAP. Metode pengumpulan data dilakukan dengan metode kepustakaan yaitu menggali informasi sebanyak mungkin dari bahan-bahan kepustakaan. Metode analisis data yang digunakan dalam penelitian ini adalah metode deskriptif kualitatif.

\section{Hasil Penelitian dan Pembahasan}

Hukum pidana merupakan salah satu sarana yang dimiliki oleh negara dalam menjalankan kewajiban memberikan perlindungan pada hak setiap warga negara untuk mendaptkan rasa aman terutama terhadap ancaman terjadinya kejahatan. Jika dibandingkan hukum yang lainnya, hukum pidana ini memiliki karakteristik yang khas yang terletak pada adanya sanksi yang sangat tegas yaitu berupa nestapa. Oleh sebab itu, sistem hukum pidana harus selalu di reevaluasi, direkonstruksi, diharmonisasikan dan diaktualisasikan secara cermat dan tepat, melalui pemahaman dan pemikiran yang utuh agar, di satu sisi handal dalam mengantisipai perkembangan kejahatan tetapi di sisi lain tidak mengancam hak asasi, harkat dan martabat manusia ${ }^{8}$.

\footnotetext{
8 Aloysius Wisnubroto, Konsep Hukum Pidana Telematika, Universitas Atma Jaya, Yogyakarta, 2011, hlm. 1.
} 
Sebagaimana diketahui bahwa sistem hukum pidana bersubstansikan sistem pemidanaan yang terdiri dari tiga pilar utama yakni, perbuatan pidana (asas legalitas), pertanggungjawaban pidana (asas culpabilitas) dan Pemidanaan. Dalam KUHP yang berlaku sebagai hukum positif di Indonesia pada saat ini (WvS) tampak dengan jelas bahwa tiga pilar utama sistem pemidanaannya masih berorientasi pada paradigma fisik (hardreality). Padahal asas-asas yang terdapat dalam Aturan Umum KUHP tersebut sangat diperlukan sebagai landasan operasional dalam penerapan aturan mengenai delik khusus, baik yang terdapat dalam KUHP maupun yang tersebar d berbagai perundang-undangan hukum pidana khusus, sejauh tidak diatur secara khusus. Akibatnya hukum pidana positif yang berlaku pada saat ini menjadi serba sulit menjangkau perkembangan kasus-kasus kejahatan berbasis hight-tech yang berkembang sangat pesat dan berparadigma non-fisik ${ }^{9}$.

Di bidang hukum pidana, analogi sebenarnya tidak termasuk bagian dari interpretasi karena sebagaimana diketahui bahwa dalam pidana terdapat asas-asas dasar yang merupakan pirinsip yang mencerminkan sifat utama hukum pidana tersebut secara filsafati, yaitu: Asas Legalitas/Legisme (Principle of Legality) yang dikenal pula dengan istilah: Asas Nullum Delictum (Nullum Crimen), yaitu asas yang menentukan bahwa tidak ada perbuatan yang dilarang dan diancam dengan pidana jika tidak ditentukan terlebih dahulu dalam perundang-undangan. Anselm von Feuerbach merumuskan asas legalitas yang dirangkai dalam satu kalimat: "Nullum crimen, nulla poena sine praevia lege" (tidak ada perbuatan pidana, tidak ada pidana tanpa ketentuang undang-undang terlebih dahulu) ${ }^{10}$. Mengenai berkaitan dengan asas legalitas dalam hukum pidana teknologi hal ini serupa dengan apa yang disampaikan Moeljatno, yang mengatakan bahwa dasar pokok dalam menjatuhi pidana pada orang yang telah melakukan perbuatan pidana adalah norma yang tidak tertulis. Dan tidak dipidana orang, apabila tidak ada kesalahan. Hal dasar ini adalah mengenai pertanggungjawaban seseorang atas perbuatannya yang telah dilakukannya. Jadi, mengenai criminal responsibility atau criminal liability. Biasanya asas legalitas ini dimaksud mengandung tiga pengertian, yaitu ${ }^{11}$ : tidak

\footnotetext{
${ }^{9}$ Ibid.

${ }^{10} \mathrm{Ibid}$.

${ }^{11}$ Moeljatno, Asas-asas Hukum Pidana, Edisi Revisi, Rineka Cipta, hlm. 27.
} 
ada perbuatan yang dilarang dan diancam dengan pidana kalau hal itu terlebih dahulu belum dinyatakan dalam suatu perundang-undang, untuk menentukan adanya perbuatan pidana tidak boleh digunakan analogi (kias), dan aturan-aturan hukum pidana tidak berlaku surut.

Secara umum, fungsi hukum adalah mewujudkan hidup bersama yang teratur sedemikian rupa sehingga keadaan tersebut dapat menunjang perkembangan pribadi manusia masing-masing dalam mencapai tujuan hidup. Hakikatnya, fungsi hukum adalah memelihara kepentingan umum dalam masyarakat, menjaga hak-hak manusia, dan mewujudkan keadilan dalam hidup bersama di masyarakat ${ }^{12}$. Berkaitan dengan fungsi hukum, Lawrence M. Friedman mengemukakan bahwa fungsi hukum adalah sebagai sarana pengawasan atau pengendalian sosial (social control), penyelesaian sengeketa (dispute settlement), dan rekayasa sosial (social engineering, redistributive, inovation) ${ }^{13}$. Sedangkan menurut Soerjono Soekanto, fungsi hukum adalah: memberi pedoman pada masyarakat tentang bagaimana mereka harus bersikap dan bertingkah laku, menjaga keutuhan masyarakat, memberikan pegangan pada masyarakat untuk melakukan pengendalian sosial14. Berdasarkan Pasal 1 KUHP dapat disimpulkan adanya asas legalitas dalam hukum pidana di Indonesia.

Asas legalitas adalah asas umum yang mengutamakan kualifikasi atas suatu tindak pidana yang harus dicantumkan dalam peraturan perundang-undangan terlebih dahulu. Jika perbuatan tersebut sudah ditetapkan, maka setiap orang yang memenuhi unsur sebagaimana diatur dalam peraturan perundang-undangan maka perbuatan tersebut dapat dikualifikasikan sebagai perbuatan pidana dan dapat dipidana. Asas legalitas, yang dirumuskan secara lengkap dalam bahasa Latin adalah nullum crimen sine lege dan Nulla poena sine lege diakui sebagai asas dasar hukum pidana di negara-negara liberal kapitalis maupun sosialis, termasuk oleh KUHP Indonesia ${ }^{15}$. Menurut Moeljatno, telah dikatakan bahwa dasar yang

12 The Huijbers, Filsafat Hukum dalam Lintasan Sejarah, Kanisius, Jakarta, 1988, hlm. 285.

${ }^{13}$ Lawrence M. Friedman, American Law, W.W Norton\&Co, New York, 1984, hlm. 11.

${ }^{14}$ Soerjono Soekanto, Pokok-Pokok Sosiologi Hukum, Raja Grafindo Persada, Jakarta, 2003, hlm. 9.

15 Andi Zainal Abidin, Hukum Pidana Bagian Pertama, Alumni, Bandung, 1987, hlm. 45. 
pokok dalam menjatuhi pidana pada orang yang telah melakukan perbuatan pidana adalah norma yang tidak tertulis. Tidak dipidana jika tidak ada kesalahan. Dasar ini adalah mengenai pertanggungjawabkannya seseorang atas perbuatan yang telah dilakukannya. Mengenai dilarang dan diancamnya suatu perbuatan, yaitu mengenai perbuatan pidananya sendiri, mengenai criminal act, juga ada dasar pokok yaitu, asas legalitas (principle of legality), asas yang menentukan bahwa tidak ada perbuatan yang dilarang dan diancam dengan pidana jika tidak ditentukan terlebih dahulu dalam perundang-undangan. ${ }^{16}$

Asas legalitas berarti menuntut adanya ketentuang peraturan perundangundangan ditetapkan terlebih dahulu dengan sah. Setelah itu perbuatan yang dilakukan oleh manusia yang terbukti memenuhi unsur-unsur tindak pidana dapat dijatuhi pidana. Dengan demikian dalam asas ini terseimpul bahwa peraturan perundang-undangan tidak dapat diberlakukan surut/mundur (retroaktif), agar hal ini menjadi jaminan kepastian hukum ${ }^{17}$.

UU ITE juga menganut asas legalitas (sebagai asas fundamental dalam hukum pidana), yaitu sebagaimana tampak dalam Pasal 54 ayat (1) bahwa undangundang ini mulai berlaku pada tanggal diundangkannya. Artinya, ketentan pidana yang ada dalam UU ITE akan dilaksanakan setelah diberlakukannya sejak tanggl 21 Aprli $2008^{18}$. Asas legalitas ini sangat krusial kepentingannya bagi penentuan apakah suatu perbuatan dikategorikan sebagai perbuatan pidana atau tidak, terlebih lagi dalam suatu kejahatan teknologi apakah masuk ke dalam masalah hukum atau masalah etika. Maka peran asas legalitas bagi landasan awal dalam menentukan perbuatan suatu tindak pidana sangat dibutuhkan. Dalam Pasal 184 KUHAP mengatur mengenai alat bukti yang sah, yaitu ${ }^{19}$ :
a) Keterangan saksi.
b) Keterangan akli.
c) Surat.
d) Petunjuk.
e) Keterangan terdakwa

\footnotetext{
${ }^{16}$ Moeljatno, Op. Cit., hlm. 25.

${ }^{17}$ Satochid Kartanegara, Hukum Pidana, Balai Lektur Mahasiswa, Bandung, 1976, hlm. 179.

18 Widodo, Apek Hukum Pidana Kejahatan Mayantara, Aswaja Pressindo, Yogyakarta, 2013, hlm. 21.

${ }^{19}$ Undang-Undang Nomor 8 Tahun 1981.
} 
Lalu pertanyaan yang muncul dari hal ini apabila kita kaitkan dengan Teknologi dan Informasi adalah, bagaimana pengaturan (legalitas) alat bukti apabila menyangkut permasalahan hukum di bidang elektronik? Tentu saja hal ini adalah alat bukti elektronik yang menjadi pembahasan pada topik ini.

Pengaturan alat bukti elektronik harus didasarkan pada sistem dan prinsip pembuktian hukum acara pidana yang berlaku di Indonesia. Definisi hukum pembuktian adalah merupakan sebagian dari hukum acara pidana yang mengatur macam-macam alat bukti yang sah menurut hukum, sistem yang dianut dalam pembuktian, syarat-syarat dan tata cara mengajukan alat bukti tersebut serta kewenangan Hakim untuk menerima, menolak, dan menilai suatu pembuktian ${ }^{20}$. Dimana sumber-sumber hukum pembuktian dalam hal ini adalah: undangundang, doktrin atau ajaran, dan juga yurisprudensi. Dan yang dimaksud dengan alat bukti adalah segala sesuatu yang ada hubungannya dengan suatu perbuatan, dimana dengan alat-alat bukti tersebut, dapat dipergunakan sebagai bahan pembuktian guna menimbulkan keyakinan hakim atas kebenaran adanya suatu tindak pidana yang telah dilakukan terdakwa ${ }^{21}$.

KUHAP belum mengatur secara tegas mengenai alat bukti elektronik yang sah. Akan tetapi berkaitan dengan legalitas alat bukti elektronik dalam sistem peradilan pidana, maka hal ini berkaitan dengan adanya asas legalitas yang menyatakan bahwa dalam Undang-Undang Nomor 11 Tahun 2008 tentang Informasi dan Transaksi Elektronik dicantumkan dalam Pasal 54 ayat (1), maka untuk menggunakan data elektronik dapat dijadikan sebagai alat bukti yang sah. UU ITE secara sah sudah mengatur mengenai hal ini. Hal ini ditunjukkan dalam Surat Mahkamah Agung kepada Menteri Kehakiman Nomor 39/TU/88/102/Pid tanggal 14 Januari 1988 menyatakan "microfilm atau microfiche dapat dipergunakan sebagai alat bukti yang sah dalam perkara pidana di pengadilan mengganti alat bukti surat, dengan catatan microfilm tersebut sebelumnya dijamin keotentikasiannya yang dapat ditelusuri kembali dari registrasi maupun berita hlm. 10 .

${ }^{20}$ Hari Sasangka dan Lily Rosita, Hukum Pembuktian Dalam Perkara Pidana, Mandar Maju, Bandung, 2003, ${ }^{21}$ Ibid 
acara"22. Legalitas alat bukti elektronik dalam UU ITE diatur dalam BAB III tentang Informasi, Dokumen, dan Tanda Tangan Elektronik, serta Pasal 44 UU ITE. Pasal 5 UU ITE disebutkan, yaitu²3:

(1) Informasi Elektronik dan/atau Dokumen Elektronik dan/atau hasil cetaknya merupakan alat bukti hukum yang sah.

(2) Informasi Elektronik dan/atau Dokumen Elektronik dan/atau hasil cetaknya sebagaimana dimaksud pada ayat (1) merupakan perluasan dari alat bukti yang sah sesuai dengan Hukum Acara yang berlaku di Indonesia.

(3) Informasi Elektronik dan/atau Dokumen Elektronik dinyatakan sah apabila menggunakan Sistem Elektronik sesuai dengan ektentuan yang diatur dalam UU ini.

(4) Ketentuan mengenai Informasi Elektronik dan/atau Dokumen Elektronik sebagaimana dimaksud pada ayat (1) tidak berlaku untuk:

a. Surat yang menurut UU harus dibuat dalam bentuk tertulis, dan

b. Surat beserta dokumennya yang menurut UU harus dibuat dalam bentuk akta notariil atau akta yang dibuat oleh pejabat pembuat akta.

Pengaturan alat bukti pada perundang-undangan tersebut menunjukkan kebergaman, tetapi keberagaman tersebut telah diatasi dengan dikeluarkannya Undang-Undang Nomor 11 Tahun 2008 tentang Informasi dan Transaksi Elektronik. Namun, ada beberapa perundang-undangan yang mengatur mengenai alat bukti elektronik dapat dijadikan alat bukti yang sah di persidangan, yaitu pada Pasal 38 Undang-Undang Tindak Pidana Pencucian Uang, yaitu: alat bukti pemeriksaan tindak pidana pencucian uang berupa:

a. Alat bukti sebagaimana dimaksud dalam Hukum Acara Pidana.

b. Alat bukti lain berupa infomasi yang diucapkan, diterima, atau disimpan secara elektronik dengan alat optik atau yang serupa dengan itu.

c. Dokumen sebagaiman dimaksud dalam Pasal 1 angka 7.

Dokumen adalah data, rekaman atau informasi yang dapat dilihat, dibaca, dan/atau didengar, yang dapat dikeluarkan dengan atau tanpa bantuan suatu sarana, baik yang tertuang di atas kertas, benda fisik apapun selain kertas, atau yang terekam secara elektronik, termasuk tetapi tidak terbatas pada:

1. Tulisan, suara, atau gambar.

2. Peta, rancangan foto, atau sejenisnya.

3. Huruf, tanda, angka, simbol atau perforasi yang memiliki makna atau dapat dipahami oleh orang yang mampu membaca atau memahaminya.

22 Josua Sitompul, Cyberspace Cybercrime Cyberlaw Tinjauan Aspek Hukum Pidana, Tata Nusa, Jakarta, 2012, hlm. 270.

${ }^{23}$ Undang-Undang Nomor 28 Tahun 2011 tentang Informasi dan Transaksi Elektronik. 
Pada prinsipnya ketentuan alat bukti elektronik yang diatur dalam UU Terorisme serupa dengan UU TPPU. Akan tetapi, UU TPPU mengatur bahw alat bukti elektronik dapat diklasifikasikan sebagai dokumen, yaitu data, rekaman, atau informasi yang dapat dilihat, dibaca, dan/atau didengar yang terekam secara elektronik. Hal ini menunjukkan bahwa dalam UU TPPU, alat bukti surat telah diperluas hingga mencakup dokumen yang terekam secara elektronik ${ }^{24}$. Pengaturan alat bukti elektronik dalam UU ITE diatur dalam BAB III tentang Informasi, Dokumen, dan Tanda Tangan Elektronik, serta Pasal 44 UU ITE. Pasal 5 ayat (1) mengatru secara tegas bahwa Informasi atau Dokumen Elektronik dan/atau hasil cetaknya, merupakan perluasan dari alat bukti elektronik telah diterima dalam sistem hukum pembuktian di Indonesia di berbagai peradilan, pidana, perdata, agama, militer, tata usaha negaram mahkamah konstitusi, termasuk arbitrase. Akan tetapi penekanan dari bagian ini adalah pengaturan alat bukti elektronik dalam hukum acara pidana di Indonesia, dan tidak membahas topik ini terkait hukum acara lainnya ${ }^{25}$.

UU ITE tidak menjelaskan apa yang dimaksud dengan perluasan dari alat bukti yang sah. Akan tetapi dalam Pasal 5 ayat (2) UU ITE memberikan petunjuk penting mengenai perluasan ini, yaitu bahwa perluasan tersebut harus sesuai dengan Hukum Acara yang berlaku di Indonesia. Mengacu kepada pembahasan sebelumnya, perluasan tesebut mengandung makna memperluas cakupan atau ruang lingkup alat bukti yang diatur dalam Pasal 184 KUHAP dan mengatur sebagai alat bukti lain, yaitu menambah jumlah alat bukti yang diatur dalam Pasal 184 KUHAP.

Mengacu kepada ketentuan-ketentuan mengenai pembuktian yang diatur alam KUHAP maka sesuai dengan Hukum Acara yang berlaku di Indonesia, maksudnya ialah bahwa harus ada alat penguji terhadap alat bukti elektronik agar alat bukti tersebut dapat dinyatakan sah di persidangan, sama seperti terhadap alat bukti lainnya, yaitu persyaratan formil dan persyaratan materiil. Persyaratan tersebut ditentukan berdasarkan jenis alat bukti elektronik yang dimaksud dalam bentukk original atau hasil cetaknya ${ }^{26}$. Persyaratan materiil alat bukti elektronik diatur alam

\footnotetext{
${ }^{24}$ Josua Sitompul, Op. Cit., hlm. 275.

${ }_{25}$ Ibid.

${ }^{26}$ Ibid.
} 
Pasal 5 ayat (3) UU ITE, yaitu Informasi atau Dokumen Elektronik dinyatakan sah apabila menggunakan Sistem Elektronik sesuai dengan ketentuan yang diatur dalam UU ITE. Lebih lanjut, Sistem Elektronik diatur dalam Pasal 15 s.d. 16 UU ITE dan dari kedua pasal ini, dapat diperoleh persayratan lebih rinci, yaitu bahwa Sistem Elektronik 27:

1. Andal, aman, dan bertanggungjawab.

2. Dapat menampilkan kembali Informasi atau Dokumen Elektronik secara utuh.

3. Dapat melindungi ketersediaan, keutuham, keotentikan, kerahasiaan, dan keteraksesan Informasi Elektronik.

4. Dilengkapi dengan prosedur atau petunjuk dan dapat beroperasi sesuai prosedur atau petunjuk yang telah ditetapkan tersebut.

Sedangkan persyaratan formil alat bukti elektronik diatur dalam Pasal 5 ayat (4) dan Pasal 43 UU ITE, yaitu²8:

1. Informasi atau Dokumen Elektronik tersebut bukanlah:

a. Surat yang menurut UU harus dbuat dalam bentuk tertulis.

b. Surat beserta dokumennya yang menurut undag-undang harus dibuat dalam bentuk akta notariil atau akta yang dibuat oleh pejabat pembuat akta.

2. Penggeledahan atau penyitaan terhadap Sistem Elektronik harus dilakukan atas izin ketua pengadilan negeri setempat.

3. Pengggeledahan atau penyitaan dan tetap menjaga terpeliharanya kepentingan pelayanan umum.

Dalam Sistem Peradilan Pidana, terutama alat bukti elektronik ini merupakan suatu hal yang sangat penting dan sangat dibutuhkan untuk menjadi bukti suatu kejahatan yang dilakukan oleh pelaku serta dibuktikan di Peradilan Pidana. Kaitan antara alat bukti elektronik ini dengan Sistem Peradilan Pidana terutama dalam Fungsi Sistem Peradilan Pidana, yaitu memiliki dua tujuan besar, yaitu untuk melindungi masyarakat dan menegakkan hukum. Selain dua tujuan tersebut, sistem peradilan pidana memiliki beberapa fungsi penting, yaitu ${ }^{29}$ :

1. Mencegah kejahatan.

2. Menindak pelaku tindak pidana dengan memberikan pengertian terhadap pelaku tindak pidana di mana pencegahan tidak efektif.

3. Peninjauan ulang terhadap legalitas ukuran pencegahan dan penindakan.

4. Putusan pengadilan untuk menentukan bersalah atau tidak bersalah terhadap orang yang ditahan.

${ }^{29}$ Tollib Effendi, Sistem Peradilan Pidana, Buku Seru, Jakarta, 2013, hlm. 13.
} 
5. Disposisi yang sesuai terhadap seseorang yang dinyatakan bersalah.

6. Lembaga koreksi oleh alat-alat negara yang disetujui oleh masyarakat terhadap perilaku mereka yang telah melanggar hukum pidana.

Melihat dari fungsi sistem peradilan pidana di atas, maka alat bukti elektronik sangat dibutuhkan sekali kegunaan dan manfaatnya, guna untuk peninjauan ulang legalitas ukuran pencegahan dan penindakan serta memberikan putusan pengadilan yang menentukan bersalah atau tidaknya terdakwa yang di sidang, dengan menggunakan alat bukti elektronik tersebut sebagai bukti bahwa terdakwa melakukan kejahatan yang di tuntut kan oleh aparat penegak hukum.

Disebutkan bahwa salah satu syarat materiil alat bukti elektronik dapat diterima di pengadilan adalah bahwa suatu informasi atau dokumen elektronik harus dapat dijamin ketersediaan, keutuhan, keotentikannya. Dalam satu transaksi elektronik akan ada begitu banyak informasi yang tercatat atau terekam di banyak alat dan perangkat. Informasi elektronik maupun dokumen elektronik bila tidak ditangani dengan benar, dapat berubah, rusak, atau hilang.

Association of Chief Police Officers (ACPO) memberikan empat prinsip dalam penanganan alat bukti elektronik, yaitu ${ }^{30}$ : Pertama, semua penanganan terhadap alat bukti elektronik (yaitu data yang diperoleh dari komputer atau media penyimpanan, atau alat dan perangkat elektronik lain) yang dilakukan oleh aparat penegak hukum tidak boleh mengakibatkan adanya perubahan atau kerusakan terhadap data agar dapat diterima di pengadilan. Kedua, dalam keadaan-keadaan dimana seseorang harus mengakses data original yang terdapat dalam komputer atau media penyimpanan, orang yang dimaksud harus memiliki kompetensi untuk melakukannya, dan harus mampu memberikan penjelasan mengenai relevansi tindakannya terhadap data dan akibat dari perbuatannya itu. Ketiga, bahwa harus ada prosedur dan proses yang jelas yang diterapkan untuk mengumpulkan dan menganalisa alat bukti elektronik. Prosedur yang dimaksud memuat penanganan alat bukti elektronik mulai dari penemuan barang bukti yang mengandung alat bukti elektronik, pembungkusan barang bukti, pemeriksaan, analisa dan pelaporan.

${ }^{30}$ Good Practice Guiede for Computer-Based Electronic Evidence, hlm. 4. 
Keempat, harus ada pihak atau pejabat yang bertanggungjawab untuk memastikan pelaksanaan kegiatan agar sesuai dengan peraturan perundang-undangan serta keseluruhan proses dan prosedur yang dimaksud.

Hal lain yang perlu diperhatikan dalam pengumpulan barang bukti yang menyimpan alat bukti elektronik ialah bahwa ada begitu banyak jenis alat dan media yang menyimpan informasi. Mengingat ada begitu banyak jenis media penyimpanan informasi dan teknologi, penanganannya pun memiliki karakteristik masing-masing. Secara umum digital forensik dibagi menjadi ${ }^{31}$ :

a. Komputer forensik, yaitu forensik yang dilakukan terhadap komputer, laptop, atau hardisk dan media penyimpanan sejenis.

b. Mobile forensik, yaitu forensik yang dilakukan terhadap telepon genggam.

c. Network forensik, yaitu forensik yang dilakukan terhadap jaringan komputer.

d. Audio forensik, yaitu forensik yang dilakukan terhadap suara.

e. Image forensik, yaitu forensik yang dilakukan terhadap gambar.

f. Video forensik, yaitu forensik yang dilakukan terhadap video dan CCTV.

Berdasarkan prinsip ACPO yang telah disebutkan di atas. Prinsip digital forensik terbagi menjadi tiga tahap, yaitu ${ }^{32}$ pengambilan (acquisition), pemeriksaan dan analisa, serta dokumen dan presentasi. Mengenai pengambilan, mengingat sifatnya yang tidak dapat diubah, dirusak, atau dihilangkan apabila tidak ditangani dengan tepat, pengamiblan informasi ata dokumen elektronik harus dilakukan dengan menjaga dan melindngi keutuhan atau integritasnya.

Dalam hal pemeriksaan dan analisa, pemeriksaan terhadap alat bukti elektronik original umumnya menggunakan perangkat keras dan perangkat lunak yang khusus dibuat untuk kepentingan digital forensik. Pemeriksanaan melakukan ekstraksi yaitu mengambil seluruh data dari media dimana data tersebut terseimpan, termasuk data yang telah terhapus sebelumnya. Pemeriksa juga menggunakan write blocker, yaitu alat yang digunakan untuk mencegah penulisan terhadap data original. Pemeriksaan terhadap salinan alat bukti elektronik yang asli, juga dapat membuat salinan dari salinan alat bukti elektronik sebagai bahan kerja.

Terkahir, berkaitan dengan dokumen dan presentasi, setiap tindakan yang dilakukan dalam pengumpulan dan pemeriksaan alat bukti elektronik harus

\footnotetext{
31 Muhammad Nuh Al-Azhar, Digital Forensic Panduan Praktis Investigasi Komputer, hlm. 25-26.

${ }^{32}$ US Department of Justice, Forensic Examination of Digital Evidence: Guide for Law Enforcement, April, 2004.
} 
didokumentasikan secara akurat dan menyeluruh. Tidak hanya tindakan dalam melakukan digital forensik, tetapi juga tindakan yang terkait dengannya, milsanya sertah terima komputer dari petugas yang mengambil barang ditempat kejadian perkara kepada pemeriksa forensik. Laporan dapat memuat proses dan tahapan yang dilakukan dalam pemeriksaan, termasuk alat dan perangkat yang digunakan. Selain itu, laporan juga perlu memuat infomasi mengenai keseluruhan data yang diperoleh serta data yang relevan dengan tindak pidana.

Penanganan yang tidak tepat terhadap komputer yang menyala dapat menghilangkan informasi elektronik yang sifatnya volatil. Tidak diberinya label ketika melakukan pemretelan kabel-kabel yang menempel di kompuer akan menyulitkan digital forensik dalam melakukan pemeriksaan dan analisa. Dalam pengumpulan alat bukti elektronik, penyidik akan menemukan berbagai informasi, baik yang relevan dengan tindak pidana, maupun yang tidak relevan. Penyidik harus menjaga kerahasian informasi, khususnya informasi terkait privasi seseorang yang tidak relevan dengan tindak pidana.

\section{Penutup}

Dari penulisan di atas, dapat disimpulkan, bahwa pengaturan (legalitas) alat bukti elektronik secara sah telah di perjelas di dalam BAB III tentang Informasi, Dokumen, dan Tanda Tangan Elektronik dalam Pasal 5, Pasal 6, dan melalui penegasan kembali di dalam Pasal 44 Undang-Undang Nomor 28 Tahun 2011 tentang Informasi dan Transaksi Elektronik. Alat bukti elektronik ini sangat dibutuhkan dalam Sistem Peradilan Pidana guna untuk menjatuhkan putusan bagi terdakwa yang di sidangkan dalam kasus kejahatan Teknologi dengan menjadikan alat bukti elektronik sebagai alat bukti yang sah di dalam persidangan peradilan pidana. Dan juga pengaturan alat bukti elektronik di dalam UU ITE tersebut di atas, merupakan perluasan dari alat bukti yang sudah di atur dalam KUHAP Pasal 184. Serta peran digital forensic dalam melakukan pengolahan alat bukti merupakan suatu langkah yang diperlukan dalam hal alat bukti elektronik akan dipergunakan sebagai alat bukti dalam persidangan. Seharusnya dalam Undang-Undang Nomor 11 Tahun 2008 tentang Informasi Teknologi dan Informasi memasukkan Pasal 
mengenai Digital Forensik guna mengolah dokumen elektronik atau barang bukti elektronik agar dapat digunakan sebagai alat bukti elektronik dalam persidangan.

\section{Daftar Pustaka}

\section{Buku}

Al-Azhar, Muhammad Nuh, Digital Forensic Panduan Praktis Investigasi Komputer.

Effendi, Tollib, Sistem Peradilan Pidana, Buku Seru, Jakarta, 2013.

Friedman, Lawrence M., American Law, W.W Norton\&Co, New York, 1984. , Good Practice Guiede for Computer-Based Electronic Evidence.

Kartanegara, Satochid, Hukum Pidana, Balai Lektur Mahasiswa, Bandung, 1976.

Moeljatno, Asas-asas Hukum Pidana, Edisi Revisi, Rineka Cipta.

The Huijbers, Filsafat Hukum dalam Lintasan Sejarah, Kanisius, Jakarta,1988.

US Department of Justice, Forensic Examination of Digital Evidence: Guide for Law Enforcement, April, 2004.

Sasangka, Hari \& Rosita, Lily, Hukum Pembuktian Dalam Perkara Pidana, Mandar Maju, Bandung, 2003.

Sitompul, Josua, Cyberspace Cybercrime Cyberlaw Tinjauan Aspek Hukum Pidana, Tata Nusa, Jakarta, 2012.

Soekanto, Soerjono, Pokok-Pokok Sosiologi Hukum, Raja Grafindo Persada, Jakarta, 2003.

Widodo, Apek Hukum Pidana Kejahatan Mayantara, Aswaja Pressindo, Yogyakarta, 2013.

Widodo, Hukum Pidana di Bidang Teknologi Informasi Cybercrime Law, Aswaja Pressindo, Yogyakarta, 2013.

Wahid, Abdul \& Labib, Mohammad, Kejahatan Mayantara (Cyber Crime), Cetakan Kesatu, Bandung: Refika Aditama, 2005.

Wisnubroto, Aloysius, Konsep Hukum Pidana Telematika, Universitas Atma Jaya, Yogyakarta, 2011.

Zainal Abidin, Andi, Hukum Pidana Bagian Pertama, Alumni, Bandung, 1987.

\section{Makalah Seminar}

Makalah disampaikan di Seminar Penegakan Hukum Tindak Pidana Mayantara, Kepolisian RI Polda Jateng Semarang.

\section{Peraturan Perundang-undangan}

Undang-Undang Nomor 28 Tahun 2011 tentang Informasi dan Transaksi Elektronik.

Undang-Undang Nomor 8 Tahun 1981. 